\title{
Pitaya Extracts Induce Growth Inhibition and Proapoptotic Effects on Human Cell Lines of Breast Cancer via Downregulation of Estrogen Receptor Gene Expression
}

\author{
Deborah de Almeida Bauer Guimarães, ${ }^{1}$ Danielle dos Santos Bonfim De Castro, ${ }^{1}$ \\ Felipe Leite de Oliveira, ${ }^{2}$ Eduardo Matos Nogueira, ${ }^{3}$ Marco Antônio Mota da Silva, ${ }^{4}$ and \\ Anderson Junger Teodoro ${ }^{1}$ \\ ${ }^{1}$ Nutritional Biochemistry Core, Food and Nutrition Program, UNIRIO, Rio de Janeiro, RJ, Brazil \\ ${ }^{2}$ Laboratory of Proliferation and Cell Differentiation, Institute of Biomedical Sciences, Federal University of Rio de Janeiro, \\ Rio de Janeiro, RJ, Brazil \\ ${ }^{3}$ Laboratory of Genomics, Molecular and Cellular Biology Program, UNIRIO, Rio de Janeiro, RJ, Brazil \\ ${ }^{4}$ Laboratory of Technology Natural Products, UEZO, Rio de Janeiro, RJ, Brazil
}

Correspondence should be addressed to Anderson Junger Teodoro; atteodoro@gmail.com

Received 13 January 2017; Revised 11 April 2017; Accepted 7 May 2017; Published 6 July 2017

Academic Editor: Elena Azzini

Copyright (c) 2017 Deborah de Almeida Bauer Guimarães et al. This is an open access article distributed under the Creative Commons Attribution License, which permits unrestricted use, distribution, and reproduction in any medium, provided the original work is properly cited.

\begin{abstract}
Breast cancer is one of the most prevalent cancers in the world and is also the leading cause of cancer death in women. The use of bioactive compounds of functional foods contributes to reduce the risk of chronic diseases, such as cancer and vascular disorders. In this study, we evaluated the antioxidant potential and the influence of pitaya extract (PE) on cell viability, colony formation, cell cycle, apoptosis, and expression of $\mathrm{BRCA}_{1}, \mathrm{BRCA}_{2}, \mathrm{PRAB}$, and $\mathrm{Er} \alpha$ in breast cancer cell lines (MCF-7 and MDA-MB-435). PE showed high antioxidant activity and high values of anthocyanins $(74.65 \pm 2.18)$. We observed a selective decrease in cell proliferation caused by PE in MCF-7 (ER ${ }^{+}$) cell line. Cell cycle analysis revealed that PE induced an increase in $G_{0} / G_{1}$ phase followed by a decrease in $\mathrm{G}_{2} / \mathrm{M}$ phase. Also, PE induced apoptosis in MCF-7 (ER ${ }^{+}$) cell line and suppressed BRCA , BRCA $_{2}$, PRAB, and Er $\alpha$ gene expression. Finally, we also demonstrate that no effect was observed with MDA-MB-435 cells (ER ${ }^{-}$) after $\mathrm{PE}$ treatment. Taken together, the present study suggests that pitaya may have a protective effect against breast cancer.
\end{abstract}

\section{Introduction}

Breast cancer is the most frequently diagnosed type of cancer around the world [1], and it is a complex disease caused by progressive genetic mutations, associated with other factors [2]. Various complications, including deaths from the disease associated with breast cancer, are due to metastasis. The rates of metastasis and mortality in breast cancer patients have decreased because of early diagnosis by mammographic screening and the implementation of adjuvant therapy. Currently, breast cancer control primarily involves surgical procedures and radiotherapy and is often supported by adjuvant chemotherapy or hormone therapies. This disease is highly resistant to chemotherapy, and there is still no effective cure for patients with advanced stages of the disease, especially in cases of hormone-independent cancer [3].

Several evidences, supported by epidemiological studies, indicate that prolonged exposure to sex hormones is one of the well-defined risk factors for breast cancer $[4,5]$. Despite the fact that the majority of breast cancers are $\mathrm{ER}^{+}$, and hormonal intervention is used to prevent disease recurrence and/or progression, the mechanisms through which estrogen contributes to malignant transformation of mammary epithelium are poorly understood. $\mathrm{ER}^{-}$tumors are associated with a worse short-term prognosis [6] and have weaker associations with reproductive risk factors [7] than $\mathrm{ER}^{+}$tumors. 
Mutations in $\mathrm{BRCA}_{1}$ are associated with predisposition to $\mathrm{ER}^{-}$breast tumors, whereas most known common susceptibility loci for breast cancer show stronger associations with $\mathrm{ER}^{+}$than with $\mathrm{ER}^{-}$tumors [8].

Carcinogenesis process results in the dysfunction of several regulatory features that keep the cells in check [9]. The balanced diet, with the diversified consumption of fruits and vegetables, exposes the body to several phenolic compounds. Over the last decade, these compounds have been widely studied and associated with benefits to human health. However, as there is a wide range of vegetables, species varieties, and differences in the compositions of these foods as well as the different localities of cultivation around the world, much research has yet to be done to elucidate the compounds present in these natural foods and their effective effects on the good health $[10,11]$.

Some reports support that the belief that components of food can affect the development of cancer in both beneficial and detrimental ways $[12,13]$. Healthy lifestyle changes, including a better diet and regular exercise, can prevent up to $40 \%$ of breast cancers [14]. The role of fresh fruits and vegetables is to help prevent or lessen the action of free radicals [15].

The pitaya is also known as the "dragon fruit," since it has a bright red peel with overlapping green fins that cover the fruit, a fact that has gained popularity in different countries of the world [16]. Hylocereus polyrhizus, which has redskinned fruits with red meat, Hylocereus undatus (red pitaya), which has red-skinned fruits with white flesh, and Hylocereus megalanthus (yellow pitaya), which has yellow skin, are the most commercialized and consumed [17]. Red dragon fruit (Hylocereus polyrhizus) or sometimes called red pitaya has been comprehensively researched for its bioactive compounds.

Many compounds present in pitaya are responsible for many pharmacological activities such as antitumor, antioxidant, and anti-inflammatory actions. Bioactive compounds have been reported to modify specific carcinogenic processes, including cancer metabolism, hormonal balance, transcription factors, cell cycle control, apoptosis, inflammation, angiogenesis, and metastasis [18]. Potential mechanisms for cancer prevention of bioactive compounds in fruits include prevention of DNA adduct formation, enhanced carcinogen elimination, decrease inflammatory processes, and a direct cytotoxic effect on tumor cells $[19,20]$.

Recent reports have indicated that pitaya extract may have a role in the prevention and treatment of breast cancer $[3,21]$. However, further studies on their role in the chemoprevention of breast cancer are warranted. In this context, the aim of the study was to evaluate the antiproliferative and proapoptotic effects of pitaya extract in MCF7 $\left(\mathrm{ER}^{+}\right)$and MDA-MB-435 (ER $\left.{ }^{-}\right)$cell lines.

\section{Methods}

2.1. Sample and Extraction. The red pitaya (Hylocereus polyrhizus) were obtained from Petropólis (Rio de Janeiro State, Brazil). Hydroalcoholic extract was obtained from the pulp of the fruits. Fruits were washed in tap water, and the pulp was separated from the skins and seeds. Approximately $50 \mathrm{~g}$ of pulp of pitaya was extracted with $50 \mathrm{~mL}$ of ethanol and $50 \mathrm{~mL}$ of distilled water and then shaken for $2 \mathrm{~h}$. After the pulp maceration period, the hydrohalic extract of pitaya was filtered on Whatman number 1 filter paper and the residual ethanol was evaporated under low pressure at $55^{\circ} \mathrm{C}$. The extracts were then lyophilized and frozen at $-20^{\circ} \mathrm{C}$ for use in the other experiments. Usually, $50 \mathrm{~g}$ of pulp yields $3 \mathrm{~g}$ of lyophilized extract.

2.2. Anthocyanin. Anthocyanins were extracted according to the method described by Abdel-Aal et al. [22] with slight modifications. Initially, $1 \mathrm{~g}$ of pitaya was extracted twice by mixing with $30 \mathrm{~mL}$ of methanol acidified with $1.0 \mathrm{~N} \mathrm{HCl}$ $(85: 15, v / v)$ and shaking on a shaker at $4^{\circ} \mathrm{C}$ for $24 \mathrm{hr}$. The crude extracts were filtered with Whatman number 1 paper. The filtrate absorbance readings were taken at $535 \mathrm{~nm}$, in Turner Model 340 spectrophotometer. To determine the anthocyanin values, we considered the dilution coefficients and the extinction coefficient of cyaniding 3-galactoside (98.2).

\subsection{Antioxidant Activity Analyses}

2.3.1. Oxygen-Radical Absorbance Capacity Assay (ORAC). The ORAC procedure used an automated plate reader (SpectraMax i3x, Molecular Devices, USA) with 96-well plates $[23,24]$. Experiments were conducted in phosphate buffer $\mathrm{pH} 7.4$ at $37^{\circ} \mathrm{C}$. Peroxyl radical was generated using $2,2^{\prime}$-azobis (2-amidino-propane) dihydrochloride which was prepared fresh for each run. Fluorescein was used as the substrate. Fluorescence conditions were as follows: excitation at $485 \mathrm{~nm}$ and emission at $520 \mathrm{~nm}$. The standard curve was linear between 0 and $50 \mathrm{mM}$ Trolox. Results are expressed as $\mu \mathrm{mol} \mathrm{TE} / \mathrm{g}$.

2.3.2. Ferric Reducing Ability (FRAP). The extracts were measured for antioxidant activity by FRAP according to Rufino et al. [25]. Aliquots of $2.7 \mathrm{~mL}$ of TPTZ reagent (ferric 2,4,6-tripyridyl-s-triazine) were mixed with $0.5 \mathrm{~mL}$ of sample extract. After $30 \mathrm{~min}$ at $37^{\circ} \mathrm{C}$ temperature, the absorbance was read at $595 \mathrm{~nm}$. The antioxidant capacity (FRAP) was expressed as $\mathrm{Fe}^{3+}$ equivalents ( $\mu \mathrm{mol} \mathrm{Fe}{ }^{3+1} \mathrm{~g}$ dry basis).

2.3.3. DPPH Assay. Aliquots of $0.5 \mathrm{~mL}$ of the extracts were mixed with $2.5 \mathrm{~mL}$ DPPH methanolic solution $(0.06 \mathrm{mM})$ and allowed to react for 1 hour, in the dark. Measurements were performed at $515 \mathrm{~nm}$ applying a Turner 340 spectrophotometer. Analysis was performed in triplicates, and the decline in the DPPH radical absorbance concentration caused by the extracts was compared to a Trolox standard. The results were expressed as $\mu \mathrm{mol}$ Trolox equivalents/g dry basis [19].

2.4. Cell Culture and Treatment Protocol. Cell lines were obtained from the Rio de Janeiro Cell Bank that certified their identity and quality (INMETRO-Rio de Janeiro, RJ, Brazil). Human breast adenocarcinoma cell lines (MCF-7 and MDAMB-435) were plated in $25 \mathrm{~cm}^{2}$ tissue culture flasks $\left(5.0 \times 10^{6}\right.$ cells/flask) and maintained routinely in the Dulbecco's modified Eagle's medium-high glucose (DMEM) supplemented 
with $10 \%$ fetal bovine serum (FBS) and $1 \%$ penicillin (PS), $\mathrm{pH}$ 7.4, under 5\% CO2 atmosphere. Stock flasks were grown to $70 \%$ confluence and subcultured routinely. Medium renewal was done 3 times weekly. For each experiment, cells were seeded at $3.5 \times 10^{5}$ cells $/ \mathrm{cm}^{2}$ density in 6 and $2 \times 10^{4}$ cells $/ \mathrm{cm}^{2}$ densities in 96-well plates for cell cycle and cell proliferation analyses, respectively. After $24 \mathrm{~h}$, medium was removed and cells were treated with increasing concentrations of PE (500 and $1000 \mu \mathrm{g} / \mathrm{mL}$ ) dissolved in DMEM. The controls, DMEM and DMEM+2\% DMSO, were included on each plate. The cells were then incubated for 24 and 48 hours.

\subsection{Cell Viability Assay}

2.5.1. MTT Assay. The status of cancer cell line viability was determined by the MTT (3-[4,5-dimethylthiazol-2-yl]-2,5diphenyltetrazolium bromide; thiazolyl blue) assay (Sigma, New York, USA) wherein the substance is a pale yellow substrate that is reduced by living cells to yield a dark blue formazan product. This requires active mitochondria, and even recently, dead cells do not reduce significant amounts of MTT. Exponentially growing cells were adjusted to $2.0 \times 10^{4} / \mathrm{cm}^{2}$ with DMEM, plated in 96-well plates (Corning, Tewksbury, MA) at $200 \mu \mathrm{L} /$ well, and incubated for $24 \mathrm{~h}$ according to the routine procedure. The cells were then incubated with PE (500 and $1000 \mu \mathrm{g} / \mathrm{mL}$ ) for 24 and $48 \mathrm{~h}$. Each well was also incubated with MTT $(10 \mu \mathrm{L} / \mathrm{well} ; 5 \mathrm{~g} / \mathrm{mL})$ for $4 \mathrm{~h}$. At $85 \mu \mathrm{L} /$ well, the liquid was removed, and at $50 \mu \mathrm{L} /$ well, sodium dodecyl sulfate was added to dissolve the solid residue. Finally, the absorbance was measured using a microplate reader (POLARIS-CELER ${ }^{\circledR}$ ) at $570 \mathrm{~nm}$. The cell proliferation inhibition rate (CPIR) was calculated using the following formula: CPIR $=(1-$ average value of experimental group/ average value of control group) $\times 100 \%$.

2.5.2. Test of Colony Formation (CFU). Breast cancer cell lines were adjusted at a density of $10^{3}$ cells/per well in a 6well plate in DMEM culture medium containing 10\% FBS for $48 \mathrm{~h}$. After this step, the cells were treated with PE at 500 and $1000 \mu \mathrm{g} / \mathrm{mL}$ with medium replace every 5 days. After 18 days, colonies were fixed with $4 \%$ paraformaldehyde (Sigma, St. Louis, USA) in PBS containing 4\% sucrose (Vetec, Rio de Janeiro, Brazil) for $20 \mathrm{~min}$ and then stained with $0.005 \%$ crystal violet (Vetec, Rio de Janeiro, Brazil) overnight at room temperature. For colonic analyses, they were washed five times with PBS for 5 min and 50 cells were counted using an Axiovert inverted microscope (Carl Zeiss, Oberkochen, Germany).

2.5.3. Trypan Blue Exclusion Test of Cell Viability. Cells were grown to about $80 \%$ confluence in 6-well plates and treated for $24 \mathrm{~h}$ and $48 \mathrm{~h}$ with red PE at $500 \mu \mathrm{g} / \mathrm{mL}$ and $1000 \mu \mathrm{g} / \mathrm{mL}$. Adherent and nonadherent cells were collected, and viability was assessed by mixing aliquots of cell suspensions with equal volumes of $0.4 \%$ trypan blue (GibcoBRL). Cells that accumulated the dye were considered dead.

2.6. Cell Cycle. Cells were rinsed briefly with calcium and magnesium-free phosphate-buffered saline and detached with trypsin at room temperature. After centrifugation, the cells were washed twice with phosphate-buffered saline and were resuspended in $500 \mu \mathrm{L}$ of ice-cold Vindelov solution [20] containing $0.1 \%$ Triton X-100, $0.1 \%$ citrate buffer and $0.1 \mathrm{mg} / \mathrm{mL}$ RNase, and $50 \mathrm{mg} / \mathrm{mL}$ propidium iodide (Sigma Chemical Co., St. Louis, MO). After 15 min of incubation, cell suspension was analyzed for DNA content by flow cytometry using a FACS Calibur flow cytometer (Becton Dickinson, Mountain View, CA). The relative proportions of cells with DNA content haploid subG $1(<2 \mathrm{n})$, diploid $\mathrm{G}_{0} / \mathrm{G}_{1}$ $(2 n), S$ phase $(>2 n$ but $<4 n)$, and $G_{2} / M$ phase $(4 n)$ were acquired and analyzed using CellQuest and WinMDI 2.9, respectively. The percentage of cell population at a particular phase was estimated with FlowJo software following the acquisition of 30,000 events. Cell dissociation procedure does not affect fluorescence under the experimental conditions that were used in this study or in any others of which we are aware. Nuclei of viable cells were gated according FL-2 $\mathrm{W} \times$ FL2-A relation.

2.7. Apoptosis Assay. Cells were resuspended in $400 \mu \mathrm{L}$ of binding buffer containing $5 \mu \mathrm{L}$ of annexin V FITC and $5 \mu \mathrm{L}$ propidium iodide (Apoptosis Detection Kit II, BDBiosciences) for $15 \mathrm{~min}$ at room temperature. Annexin $\mathrm{V}$ binding was evaluated by flow cytometry (FACScalibur, BD Biosciences), and after acquisition of 30,000 events, the data were analyzed in CellQuest and FlowJo software.

2.8. Gene Expression Analysis. Total RNA was extracted from the studied cells using Trizol ${ }^{\circledR}$ Reagent (Invitrogen) according to the manufacturer's instructions. RNA yield and quality were determined by a spectrophotometer Nano-Drop ND1000 V3.2 (Nanodrop Technologies, Wilmington, DE). Equal amounts (500 ng) of RNA from cells were reverse transcribed with cDNA synthesis kit "Superscript II First-Strand Synthesis System for RT-PCR" (Invitrogen) and Oligo (dT) primer (Invitrogen). The cDNA was used as a template for subsequent real-time polymerase chain reaction (RT-PCR). Quantitative RT-PCR was done in a StepOnePlus ${ }^{\mathrm{TM}}$ RealTime PCR System (Life Technologies) using SYBR Green (Applied Biosystems, Grand Island, NY) following the manufacturer's instructions and using primers as shown in Table 1. The expression levels of ERBB2, GSTM1, BRCA ${ }_{1}$, $\mathrm{BRCA}_{2}, \mathrm{PRAB}$ (progesterone receptor isoform $\mathrm{A}$ and $\mathrm{B}$ ), $\mathrm{ER} \alpha$ (estrogen receptor $\alpha$ ), and GPR30 (a G proteincoupled receptor for estrogen) mRNA were all normalized with $\beta$-actin and GADPH (glyceraldehyde-3-phosphate dehydrogenase) expression level. For the evaluation of the quality of RT-PCR products, analyses of the melt curve were performed after each assay. The expression is relative to the measure using the $\Delta \Delta \mathrm{CT}$ technique with $\beta$-actin and GADPH genes as the reference genes.

2.9. Statistical Analysis. The results presented are the mean and the corresponding standard deviation of three independent experiments performed in triplicate $(n=9)$. Data were analyzed using GraphPad Prism statistical software (version 5.04, GraphPad software, San Diego, CA). The univariate analysis of variance (ANOVA) with the Tukey posttest at a 
TABle 1: Primer sequences for the reverse transcription-quantitative polymerase chain reaction.

\begin{tabular}{lcc}
\hline Gene & Forward primer & Reverse Primer \\
\hline ERBB2 & CCGTGCCACCCTGAGTGT & AGCCTCCGGTCCAAAACAG \\
GSTM1 & TCCCTCTTCACTCCCCCTAAA & GGGTAGCTGAGGCTTCAAAGG \\
BRCA $_{1}$ & CTGCTCAGGGCTATCCTCTCA & TGCTGGAGCTTTATCAGGTTATGT \\
BRCA $_{2}$ & CCACAGCCAGGCAGTCTGTAT & AGAACACGCAGAGGGAACTTG \\
PRB & CCTGAAGTTTCGGCCATACC \\
PRAB & GGCTACGAAGTCAAACCCAGTT & CAGGGCCGAGGGAAGAGT \\
ER $\alpha$ & CTGTTTGCTCCTAACTTGCTCTTG \\
GAPDH & ATGGAAATCCCATCACCATCTT & CAATTGCCTTGATGAGCTCTCTAA \\
\hline
\end{tabular}

TABLE 2: Bioactive potential of pitaya evaluated by different methods.

\begin{tabular}{lcccc}
\hline Pitaya & $2.0 \mathrm{mg} / \mathrm{mL}$ & $5.0 \mathrm{mg} / \mathrm{mL}$ & $10.0 \mathrm{mg} / \mathrm{mL}$ & $R^{2}$ \\
ORAC assay $(\mu \mathrm{M}$ Trolox/g) & $140.50 \pm 1.90$ & $560.00 \pm 48.90$ & $1079.70 \pm 75.20$ & 0.9943 \\
FRAP assay $\left(\mu \mathrm{mol} \mathrm{Fe}_{2} \mathrm{SO}_{4} / \mathrm{g}\right)$ & $909.20 \pm 68.46$ & $1698.64 \pm 33.17$ & $2519.36 \pm 53.99$ & 0.9621 \\
DPPH assay $(\%$ reduction) & $33.05 \pm 0.32$ & $73.01 \pm 0.38$ & $83.99 \pm 0.30$ & 0.8892 \\
\hline & Pulp & Peel & Total anthocyanins (fruit) & Total anthocyanins (pitaya extract) \\
Total anthocyanins $(\mathrm{mg} / \mathrm{g})$ & $19.14 \pm 0.52$ & $8.36 \pm 2.70$ & $27.50 \pm 1.61$ & $74.65 \pm 2.18$ \\
\hline
\end{tabular}

Results expressed in mean \pm standard error.

95\% confidence level was used to test cell viability, cell cycle, and apoptosis rate.

\section{Results}

3.1. Bioactive Properties of Red Pitaya. Natural and synthetic antioxidants are widely used in modern medicine. In the comparison of the antioxidant assays, an important bioactive potential in pitaya $(10 \mathrm{mg} / \mathrm{mL})$ was identified in ORAC values $(1079.70 \pm 75.20 \mu \mathrm{M}$ Trolox/g), FRAP assay (2519.36 $\pm 53.99 \mu \mathrm{mol}$ sulfate ferrous/g), and DPPH reduction $(83.99 \pm 0.30 \%)$ (Table 2$)$. There is a need for screening studies in order to identify the mode of action of different antioxidant compounds (enzymatic and nonenzymatic in addition, comparing between synthetic and natural antioxidant compounds) by different assays [26].

Pitaya contained significant levels of total anthocyanins (Table 2). The pulp showed a significantly higher anthocyanin content $(19.14 \pm 0.52 \mathrm{mg} / \mathrm{g})$ in comparison with peel $(8.36 \pm 2.70 \mathrm{mg} / \mathrm{g})$.

\subsection{Effect of Pitaya Extract (PE) on Cell Viability}

3.2.1. MTT Assay. The treatment with PE for $24 \mathrm{~h}$ decreased MCF-7 cell viability from the concentration of $250-1000 \mu \mathrm{g} / \mathrm{mL}$, showing a mean reduction around $25.15 \%(p<0.05)$ (Figure 1(a)). After $48 \mathrm{~h}, \mathrm{PE}$ induced a higher inhibition of cell viability from the concentration of $2.5 \mu \mathrm{g} / \mathrm{mL}$ (by $29.33 \%$ compared with the control group, $p<0.05$ ), and the maximum inhibition was obtained with $1000 \mu \mathrm{g} / \mathrm{mL} \quad(40.22 \%, p<0.05)$ (Figure 1(b)). Our data showed an important cell growth inhibition on MCF-7 cell after PE treatment (500 $\mu \mathrm{g} / \mathrm{mL}$ and $1000 \mu \mathrm{g} / \mathrm{mL}$ ) (Figure $1(\mathrm{c})$ ).
As shown in Figures 1(d) and 1(e), a slight decrease in MDA-MB-435 cell viability was observed only in high concentrations of $\mathrm{PE}(500$ and $1000 \mu \mathrm{g} / \mathrm{mL})$ with maximum inhibition of $20 \%$ compared with control group after $48 \mathrm{~h}(p<0.05)$.

3.2.2. Test of Colony Formation (CFU). The next step was to analyze the effect of $\mathrm{PE}$ on the clonogenic property of MCF-7 and MDA-MB-435 cells. According to the literature, cell groups with fewer than 50 cells were not considered as colonies [27]. Our data showed that the clonogenic ability of MCF-7 cells was inhibited in the presence of PE (500 and $1000 \mu \mathrm{g} / \mathrm{mL}$ ) (Figure 2). Maximum reduction of clonogenic ability was obtained when $1000 \mu \mathrm{g} / \mathrm{mL}$ of PE (about $70 \%,{ }^{* *} p<0.001$ ) was used (Figure 2). No effect in colony formation was observed in MDA-MB-435 cell line after $\mathrm{PE}$ incubation.

3.2.3. Trypan Blue Exclusion. Another assay for cell proliferation was used to confirm the effect of PE in breast cancer cell lines. PE induced an inhibition of proliferation in MCF-7 cell line after 24 and $48 \mathrm{~h}$ from the concentration of $500 \mu \mathrm{g} / \mathrm{mL}$ (by $50 \%$ compared with the control group, $p<0.05$ ), and the maximum inhibition was obtained with $1000 \mu \mathrm{g} / \mathrm{mL}$ $(80 \%, p<0.05)$. Corroborating with other methods used, when MDA-MB-435 cells were treated with PE for $24 \mathrm{~h}$ and $48 \mathrm{~h}$, no changes in cell proliferation were detected when compared to untreated cells (Figure 3).

3.3. Effect of Pitaya Extract on Cell Cycle Progression. We next questioned whether PE would have any effect on cell cycle arrest in breast cancer cell lines. After $24 \mathrm{~h}$ and $48 \mathrm{~h}$ of treatment, PE caused an increase in the percentage of cells in the $\mathrm{G}_{0} / \mathrm{G}_{1}$ phase, with a corresponding decrease in the $\mathrm{G}_{2} / \mathrm{M}$ 


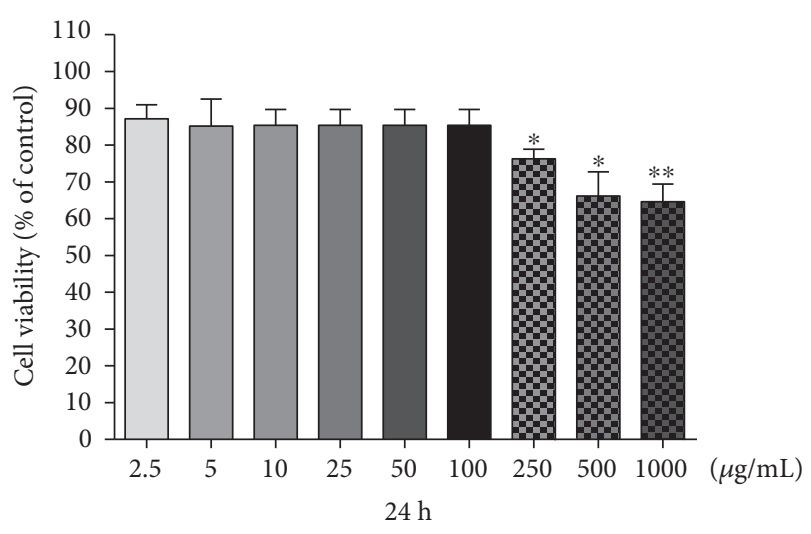

(a)

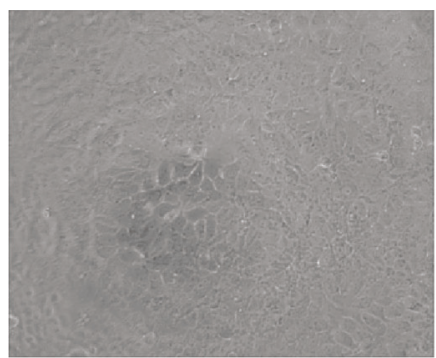

C

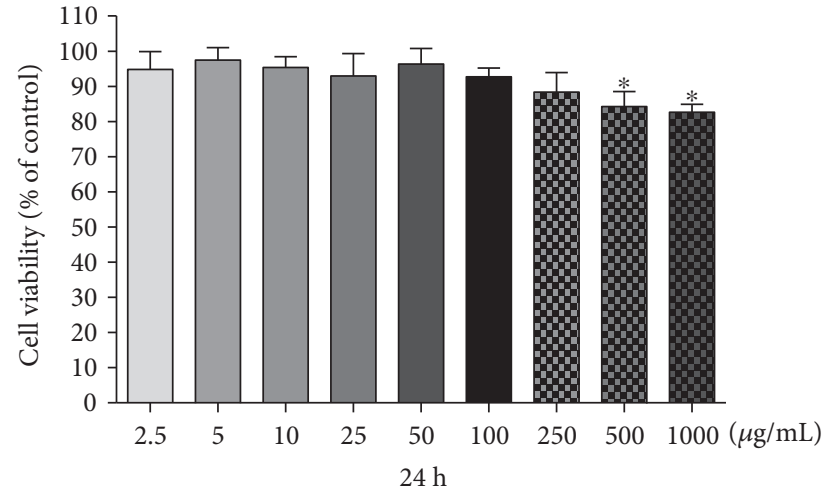

(d)

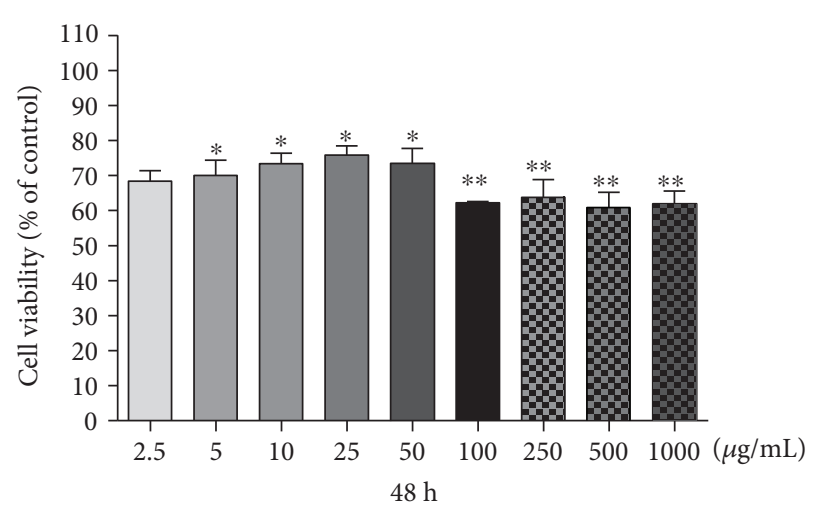

(b)

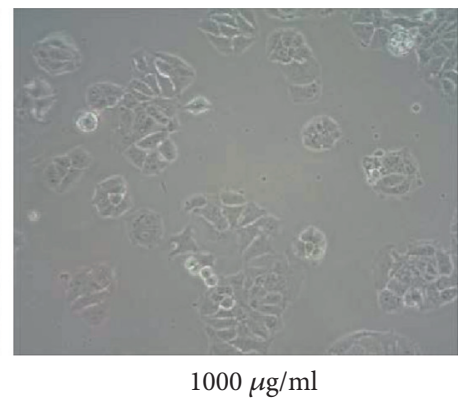

(c)

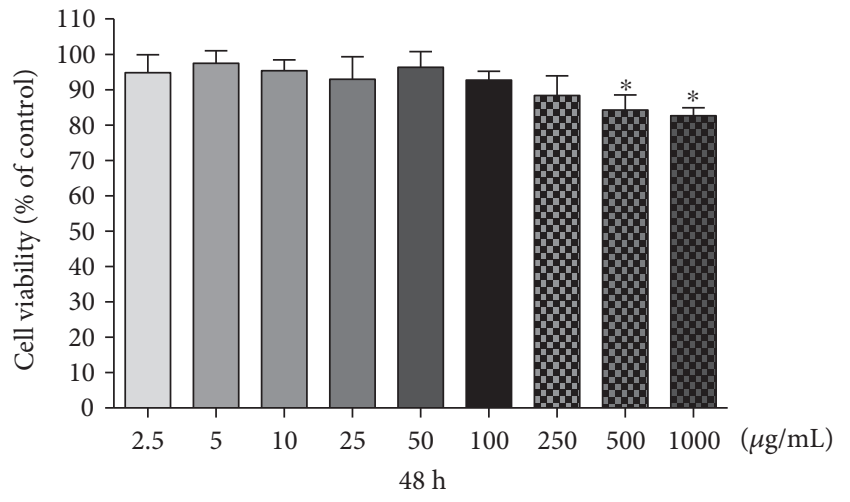

(e)

FIGURE 1: Effect of PE (2.5-1000 $\mu \mathrm{g} / \mathrm{mL})$ on viability of MCF-7 (a, b) and MDA-MB-435 (d, e) cells at different time intervals after exposure using MTT assays. The experiment is expressed as mean \pm standard error, and differences significant between treated cells with PE were compared using the Tukey test $\left({ }^{*} p<0.05 ;{ }^{* *} p<0.01\right)$. Phase contrast microscopy of MCF-7 cells (treated for $48 \mathrm{~h}$ with 500 and $1000 \mu \mathrm{g} / \mathrm{mL}$ of PE) was observed on 96-well culture plates (c).

phase, indicating a growth arrest of MCF-7 cells after that time (Figure 4 and Table 3). Corroborating with the data from cell proliferation, after $24 \mathrm{~h}$ and $48 \mathrm{~h}$ of treatment with $\mathrm{PE}$, no changes in cell cycle profile of MDA-MB-435 cells were detected when compared to untreated cells (Figure 4 and Table 3).

3.4. Effect of Pitaya Extract on Apoptosis Assay. Flow cytometry analysis showed that treatment for $24 \mathrm{~h}$ and $48 \mathrm{~h}$ with $\mathrm{PE}$ at concentrations of 500 and $1000 \mu \mathrm{g} / \mathrm{mL}$ did not induce apoptosis in MDA-MB-435 cells. However, when MCF-7 cells were treated under the same conditions for 24 and
$48 \mathrm{~h}$, an increase in the number of apoptotic cells was detected (Figure 5).

3.5. Gene Expression Profile. The role of $\mathrm{BRCA}_{1}, \mathrm{BRCA}_{2}$, $\mathrm{PRAB}$, and $\operatorname{Er} \alpha$ genes as an oncogene responsible for the downregulation of the incidence of cancer progression is well established in a wide variety of tumors, including breast tumors. To study molecular mechanisms by which PE interferes in breast cancer progression, we investigated expression profile of several related genes (Figure 6). In MCF-7 cell line, PE treatment promoted a downregulation of $\mathrm{BRCA}_{1}, \mathrm{BRCA}_{2}$, PRAB, and Er $\alpha$ genes. Conversely, in MDA-MB- 435 cells, no 


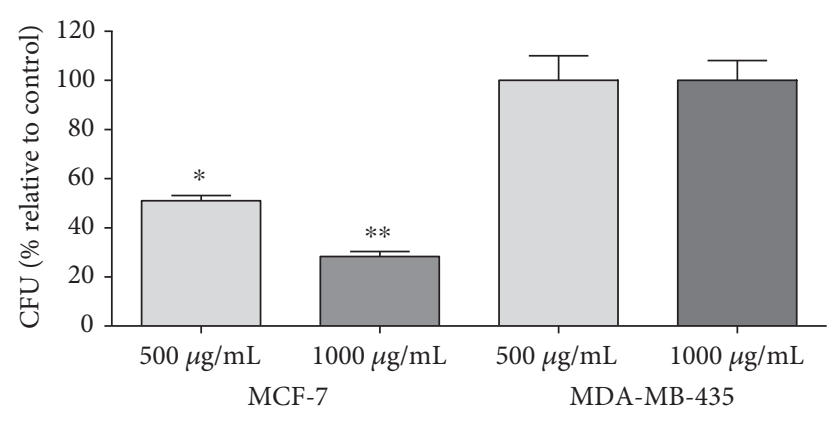

Figure 2: Formation of MCF-7 and MDA-MB-435 colonies. The number of MCF-7 and MDA-MB-435 colonies was determined after 18 days of culture in DMEM supplemented with $10 \%$ FCS containing PE at concentrations of 500 and $1000 \mu \mathrm{g} / \mathrm{mL}$. Data are presented as mean \pm standard deviation of 3 independent experiments, each performed at least in duplicate. * indicates significant differences from the control group $\left({ }^{*} p<0.05 ;{ }^{* *} p<0.01\right)$.

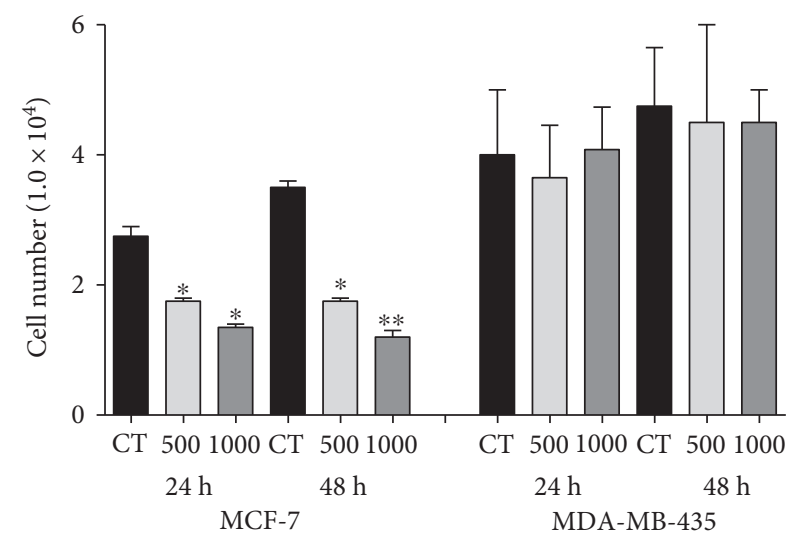

FIGURE 3: Effect of PE on cell proliferation of MCF-7 and MDAMB-435 after 24 hours and 48 hours treatment using trypan blue exclusion. Data are presented as mean \pm standard deviation of 3 independent experiments, each performed at least in duplicate. * indicates significant differences from the control group $\left({ }^{*} p<0.05 ;{ }^{* *} p<0.01\right)$.

changes in gene expression profile cells were detected when compared to untreated cells (Figure 6).

\section{Discussion}

The present study provided several sets of information on the antioxidant activity of $\mathrm{PE}$ and their effects on the cell viability, cell cycle, and apoptosis of MCF-7 and MDA-MB-435 cells. Breast cancer is the most common cause of cancer in women and the large international variation in breast cancer rates, coupled with the rapidly increasing rates observed in secular trend studies. Although dietary factors have long been suspected to be implicated in breast cancer etiology, few convincing dietary risk factors have been identified [6]. Fruits and vegetables contain numerous constituents that may reduce breast cancer risk, including antioxidants and several vitamins which can prevent cancer [28].
The red pitaya features functional potential related to its high antioxidant activity [21]. Hylocereus species were responsible for the major antioxidant capacity [29], and some studies showed that the peels also contain more or less antioxidant properties due to their color. Thus, both the peels and the pulps could be beneficial especially in food and pharmaceutical industry [30]. The main mechanism of antioxidant action in foods is radical scavenging activity. Therefore, many methods had been developed in which the antioxidant activity was evaluated by the scavenging of synthetic radicals in polar organic solvents such as ethanol [17].

In previous studies evaluating extracts of other fruits by ORAC assay, it reported lower ORAC values than those found in this study. The antioxidant capacity of the hydroalcoholic concentrated extract of red grape pomace showed $22.94 \mu \mathrm{M}$ of Trolox/g for the ORAC assay. Already concentrate pitaya extract (PE) showed high antioxidant capacity with a reduction of up to $1000 \mu \mathrm{mol}$ Trolox $/ \mathrm{g}^{-1}$ [31]. The US Department of Agriculture [32] published, as part of the National Programme for Food and Nutrient Analysis, a study containing data on the antioxidant capacity of concentrated fruit extracts, using the ORAC method. Among the tested fruits were the blackberry $(88.57 \mu \mathrm{M}$ of Trolox $/ \mathrm{g})$, raspberries $(37.98 \mu \mathrm{M}$ of Trolox/g), and a strawberry (32.26 $\mu \mathrm{M}$ of Trolox/g).

FRAP is the only assay that directly measures antioxidants in a sample. The other assays are indirect because they measure the inhibition of reactive species (free radicals) generated in the reaction mixture, and these results depend strongly on the type of reactive species used. Mancini-Filho et al. [33] showed that those with average FRAP values higher than those found in the literature for other fruit extracts are also considered high potential antioxidants. The reducing potential of PE in this study was higher than the antioxidant capacity of some concentrated extracts of nontraditional Brazilian fruits such as camu-camu and uvaia jambolan. The fruits of camu-camu showed the highest antioxidant capacity, with a value of $2501.5 \pm 74.5 \mu \mathrm{mol}$ sulfate ferrous $/ \mathrm{g}$. Acerola and the netting-black are also significant because the camu-camu showed the highest values, $1995.8 \pm 47$ and $28.4 \pm 908.95 \mu \mathrm{mol}$ sulfate ferrous/g, respectively. The fruits of jambolan $(172.8 \pm 10.8 \mu \mathrm{mol}$ sulfate ferrous/g) and uvaia $(407.5 \pm 34.9 \mu \mathrm{mol}$ sulfate ferrous/g) showed lower values than those of pitaya.

Breast cancer cell lines MCF-7 and MDA-MB-435 are well known and widely used in studies on growth properties, regulatory mechanisms, and therapy of breast cancers. Our results showed for the first time that PE shows antitumorigenic effects on hormonal receptor-positive breast cancer MCF-7 cells. The epithelial cell line MCF-7 shows estrogen and progesterone receptors and low metastatic potential. Holliday and Speirs classified MCF-7 as cell line luminal with $\mathrm{ER}^{+}, \mathrm{PR}^{+/-}, \mathrm{HER} 2^{-}$, and $\mathrm{Ki} 67$ low endocrine responsive and often chemotherapy responsive [34].

Recently, Wang et al. [35] demonstrated that differences between MCF-7 and MDA-MB-435 in 229 genes were mainly implicated in the biological functions related to cell adhesion and motion, antigen processing and presentation (via MHC class II), hormone response, extracellular structure 


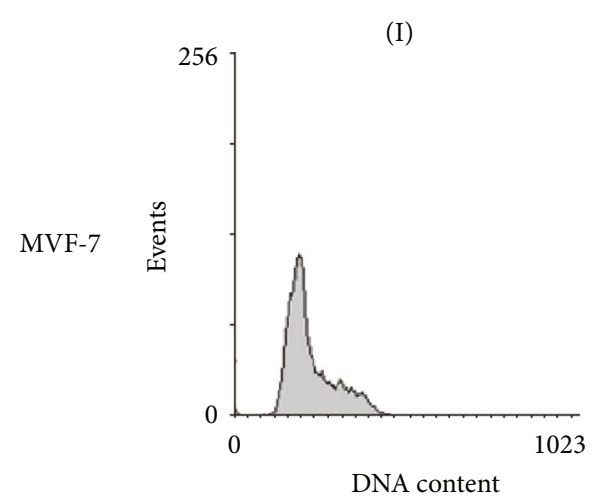

(I)

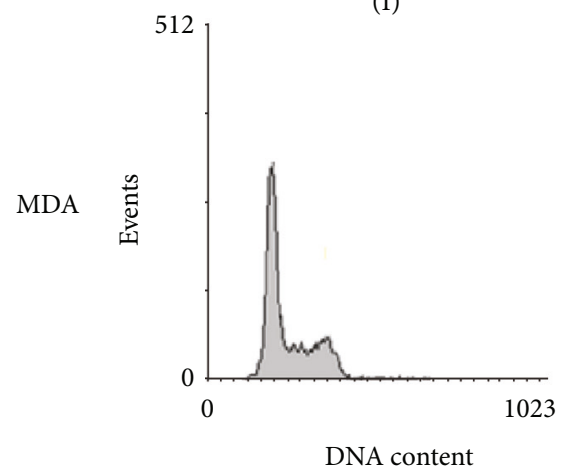

DNA content
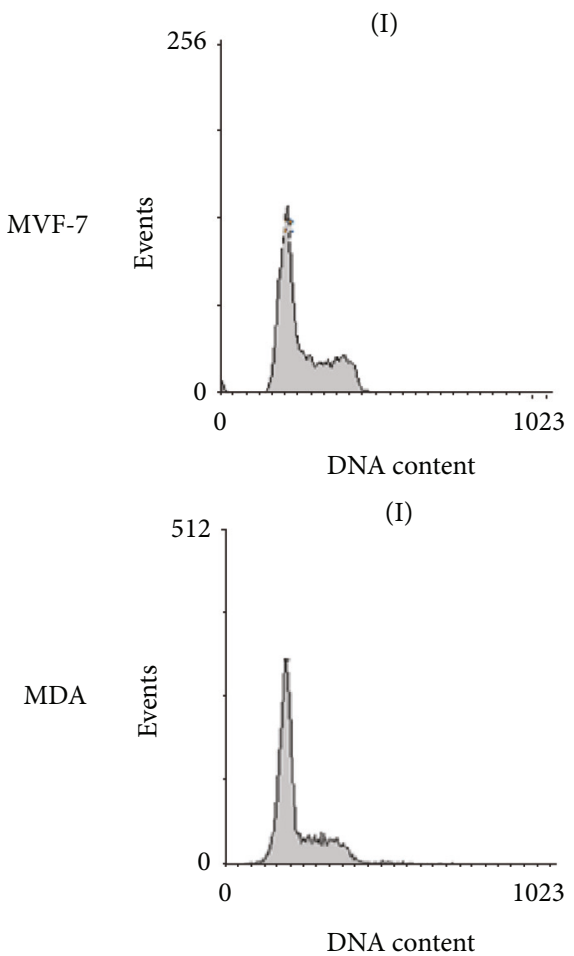

$24 \mathrm{~h}$
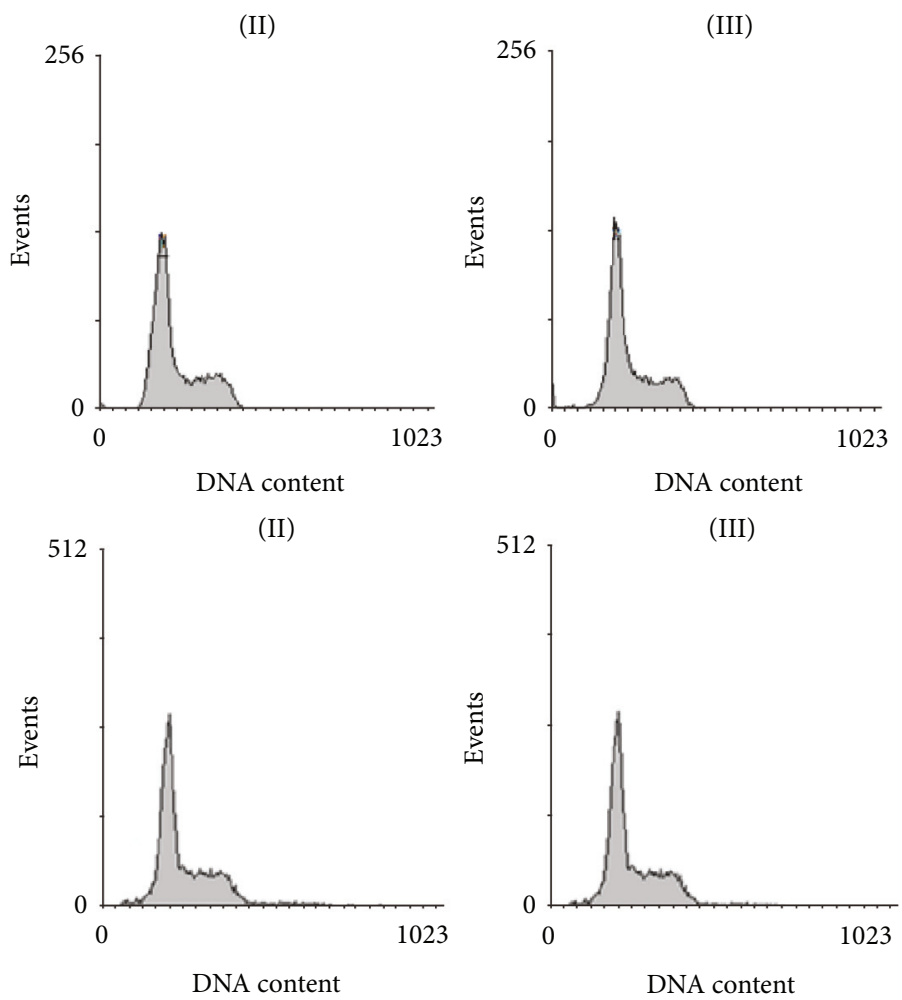

$48 \mathrm{~h}$
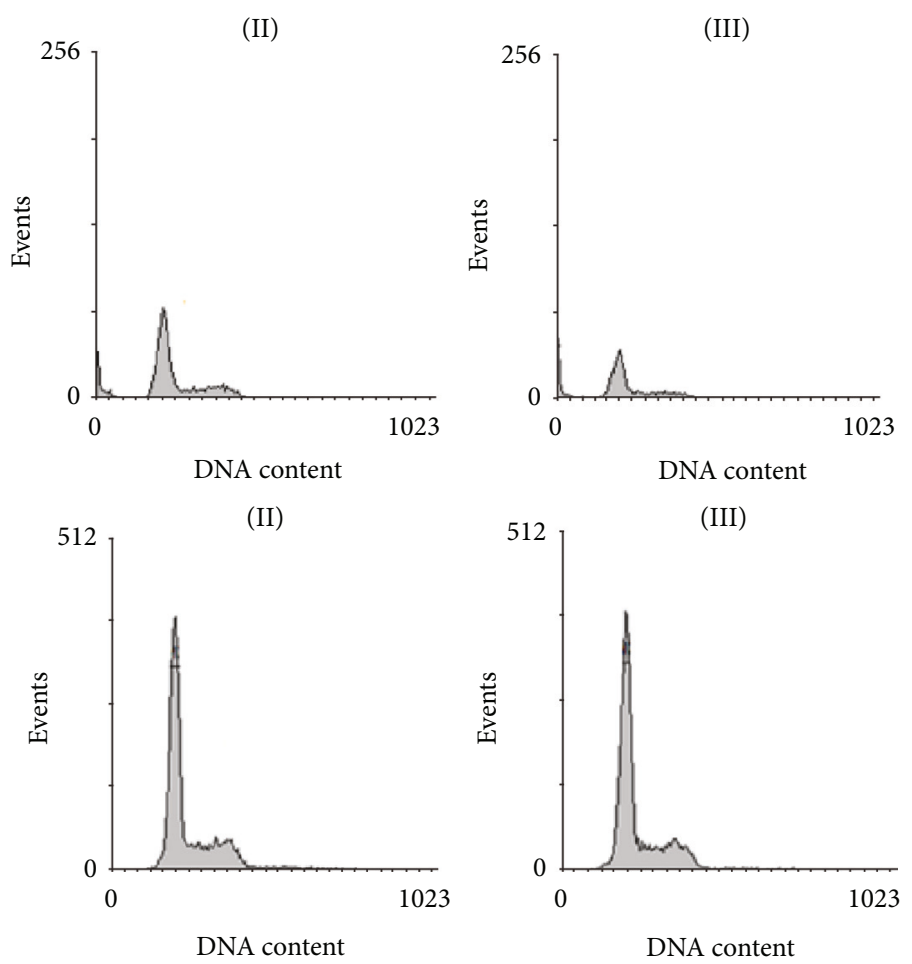

FIgURE 4: Effect of PE on cell cycle progression in MCF-7 and MDA-MB-435 cells after 24 and $48 \mathrm{~h}$ exposure. Data are presented as mean \pm standard deviation of 3 independent experiments, with significant differences between the untreated cells (I) and treated with PE 500 (II) and 1000 (III) $\mu \mathrm{g} / \mathrm{mL}$ compared by the Tukey test. 
TABLE 3: Effect of PE on cell cycle progression in MCF-7 and MDA-MB-435 cells after $24 \mathrm{~h}$ and $48 \mathrm{~h}$ exposure.

\begin{tabular}{|c|c|c|c|c|c|}
\hline Cell line & Incubation time & Cell cycle phases & Control (CT) & $500 \mu \mathrm{g} / \mathrm{mL}$ & $1000 \mu \mathrm{g} / \mathrm{mL}$ \\
\hline \multirow{6}{*}{ MCF-7 } & \multirow{3}{*}{$24 \mathrm{~h}$} & $\mathrm{G}_{0} / \mathrm{G}_{1}$ & $59.59 \pm 0.16$ & $63.47 \pm 2.07^{*}$ & $65.02 \pm 0.23^{*}$ \\
\hline & & S & $16.91 \pm 1.20$ & $14.03 \pm 0.61$ & $14.80 \pm 2.36$ \\
\hline & & $\mathrm{G}_{2} / \mathrm{M}$ & $19.28 \pm 1.87$ & $19.77 \pm 1.42$ & $17.48 \pm 3.22$ \\
\hline & \multirow{3}{*}{$48 \mathrm{~h}$} & $\mathrm{G}_{0} / \mathrm{G}_{1}$ & $58.49 \pm 0.45$ & $65.40 \pm 1.10^{*}$ & $69.61 \pm 3.90^{*}$ \\
\hline & & S & $16.45 \pm 0.55$ & $10.63 \pm 0.25$ & $13.64 \pm 1.71$ \\
\hline & & $\mathrm{G}_{2} / \mathrm{M}$ & $22.28 \pm 0.93$ & $20.19 \pm 0.04^{*}$ & $15.66 \pm 3.72^{* *}$ \\
\hline \multirow{6}{*}{ MDA-435 } & \multirow{3}{*}{$24 \mathrm{~h}$} & $\mathrm{G}_{0} / \mathrm{G}_{1}$ & $62.30 \pm 1.12$ & $61.99 \pm 1.99$ & $61.60 \pm 0.64$ \\
\hline & & S & $14.84 \pm 0.43$ & $14.93 \pm 0.24$ & $14.87 \pm 0.51$ \\
\hline & & $\mathrm{G}_{2} / \mathrm{M}$ & $19.90 \pm 1.29$ & $19.83 \pm 2.04$ & $18.88 \pm 0.68$ \\
\hline & \multirow{3}{*}{$48 \mathrm{~h}$} & $\mathrm{G}_{0} / \mathrm{G}_{1}$ & $69.64 \pm 1.18$ & $70.64 \pm 0.80$ & $70.01 \pm 1.85$ \\
\hline & & S & $11.88 \pm 0.89$ & $11.30 \pm 0.62$ & $11.50 \pm 0.53$ \\
\hline & & $\mathrm{G}_{2} / \mathrm{M}$ & $15.17 \pm 1.03$ & $15.52 \pm 0.52$ & $15.76 \pm 0.83$ \\
\hline
\end{tabular}

The cell cycle phases and quantitative results are illustrated in accordance with the exposure time and PE concentration. The experiment is expressed as mean \pm error standard. $*$ indicates significant differences from the control group $\left({ }^{*} p<0.05 ;{ }^{* *} p<0.01\right)$.
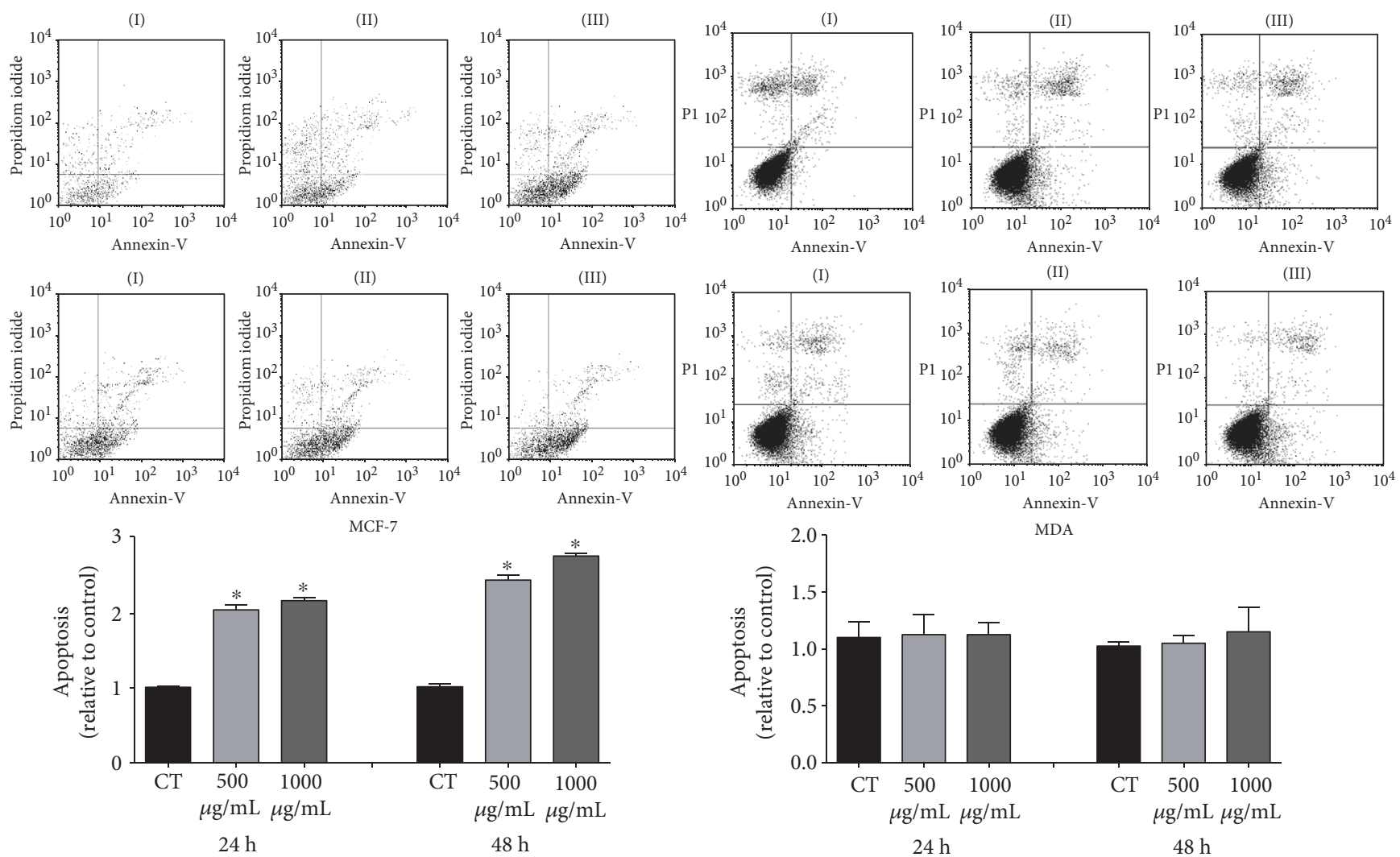

FIgURE 5: Detection of apoptotic MDA-MB-435 and MCF-7 cells by flow cytometry under PE stimulation at the concentrations of 500 and $1000 \mu \mathrm{g} / \mathrm{mL}$ for $24 \mathrm{~h}$ and $48 \mathrm{~h}$. Data are expressed as mean \pm standard deviation relative to the control, of 3 independent experiments, each performed with at least 3 replicates. * indicates significant differences from the control group $\left({ }^{*} p=0.05\right)$.

organization, tissue remodeling, and cell proliferation regulation. A microarray analysis has indicated that the gene expression pattern of the human MDA-MB-435 [4] resembles that of human melanoma cell lines $[5,36]$. This cell line has fusiform morphology and is considered luminal with low degree of invasion in Matrigel. The epithelial cell line MDA-
MB-435 does not express hormone receptors and has a high metastatic potential and high tumorigenicity [37].

According to Ge et al. [38], MDA-MB-435 cell line is resistant to drugs in vitro breast cancer, due to the presence of high levels of GSTP1 mRNA expression when compared to the levels expressed in MCF-7. Patients with breast cancer 

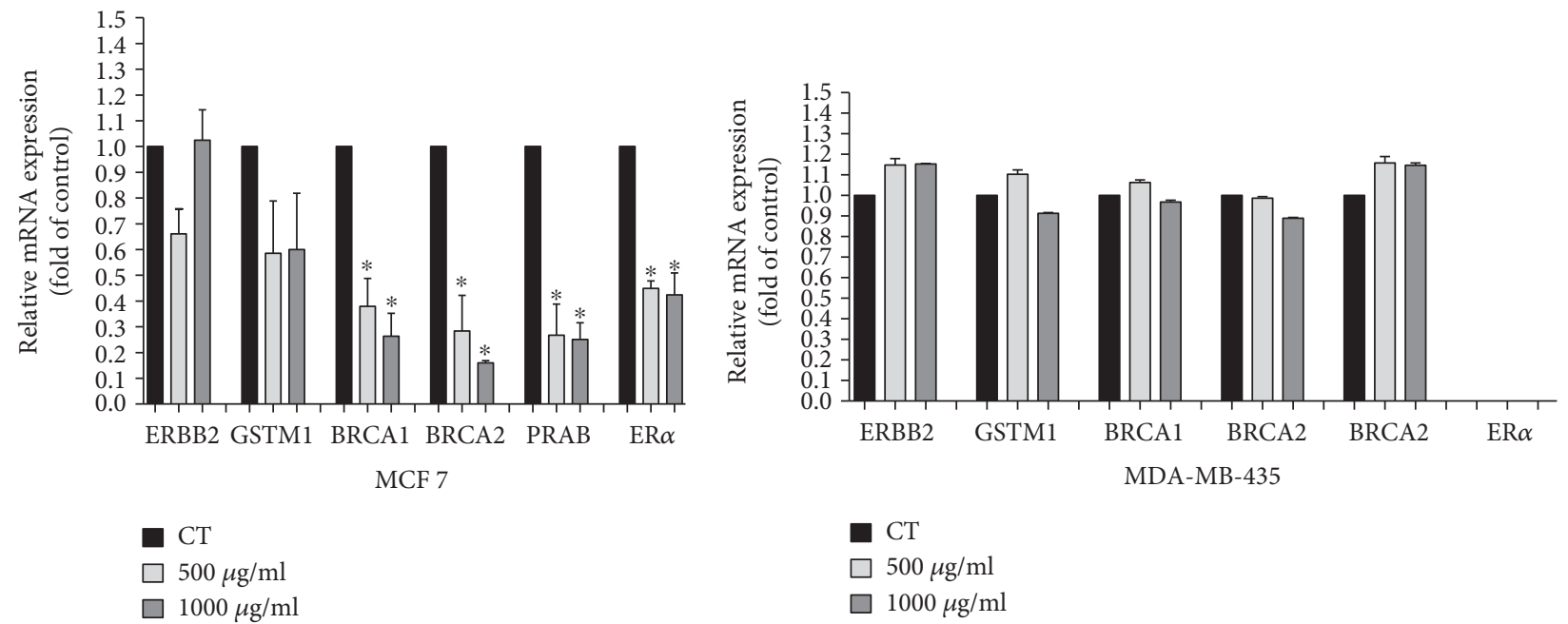

FIGURE 6: Profile of gene expression in MCF-7 and MDA-MB-435 cells. Quantitative analysis of real-time PCR in different genes associated with cancer progression, after $48 \mathrm{~h}$ incubation with PE. Data are presented as mean \pm standard deviation of 3 independent experiments, each performed at least in triplicate. Differences significant between treated cells with PE (500 and $1000 \mu \mathrm{g} / \mathrm{mL})$ were compared using the Tukey test $\left({ }^{*} p<0.05\right)$.

with the allele GSTP1 $105 \mathrm{Val}$ are more likely to have a tumor with advanced histological grade, lymph node metastases, and negative estrogen receptor. The toxic damage to the genomic DNA in somatic cells not only induces carcinogenesis but also means that there is the development of tumors with more aggressive features, with poor differentiation, independent growth hormones, and metastatic potential. Probably, this is due to difference in the characteristic of aggressiveness between MCF-7 and MDA-MB-435 cell lines, since the MCF-7 cell line has hormone receptors and is more sensitive to the action of therapeutic drugs.

Pitaya has recently drawn much attention, not only because of their striking color and economic value as food products but also for their health properties [39]. For example, red pitaya was reported to offer many health benefits including chemoprevention of cancer, anti-inflammatory and antidiabetic effects, and a reduction in the mortality risk of cardiovascular disease [40], as well as antioxidative properties conferred by its betacyanin content [41]. Asmah et al. [42] reported that a red and white pitaya pulp are rich in polyphenols and a methanol extract showed promising antioxidant and antiproliferative capacity when used to treat cervix cancer cells (HeLa) and cytotoxic effect on human oral cancer cell metastases induced by B16-F10 melanoma.

Cell cycle deregulation is a fundamental aspect in cancer development. Deregulation of cell cycle has been linked with cancer initiation and progression [43]. Thus, cell cycle has emerged as one of the attractive therapeutic targets in the treatment of cancer [44].

Neoplastic cells contained in cell proliferation with a large proportion of cells in $S$ phase and $G_{2} / M$ [45]. The efficiency of a bioactive compound in food cancer control can be judged by its ability to block the cell cycle phases $\mathrm{G}_{0} / \mathrm{G}_{1}$ and $G_{2} / M$, reducing the proportion of cells in $S$ phase [46]. $\mathrm{PE}$ promoted an increase in the percentage of cells in the $\mathrm{G}_{0} / \mathrm{G}_{1}$ phase, followed by reduction of cells in the $\mathrm{G}_{2} / \mathrm{M}$ phase, indicating an arrest in the growth and proliferation of MCF-7 cells after this period. One of the important and limiting aspects of the cell cycle is cell progression in the first phase $\left(G_{1}\right)$ of the $S$ phase, which has its control affected in cancer [47].

There is an urgent need to develop innovative ways to treat breast cancer that has become resistant to apoptosis therapies. Apoptosis in clinical practice is a potential target for therapeutic use of programmed cell death or to understand the mechanisms of resistance to radiotherapy and chemotherapy. When cells become old or damaged, they die by apoptosis, necrosis, or a combination of the two and are replaced with new cells. On the other hand, cancer cells are immortal since they are resistant to apoptosis. Chemotherapy kills cancer cells through apoptosis and/or necrosis [48].

According Sreekanth et al. [49], pitaya extract compounds (betacyanin and anthocyanin) and pigments act on K562 cells that lead to human chronic myeloid leukemia altering the integrity of the mitochondrial membrane, leading to leakage of cytochrome c, caspase activation, and nuclear disintegration. These biochemical changes are reflected in structural changes typical of cells undergoing apoptosis (programmed cell death).

In this regard, the findings presented here coupled to the dragon fruit extract inhibited the viability and proliferation of human breast adenocarcinoma MCF-7, and it was found that these bioactive compounds present in the dragon fruit also interfere in the distribution phases of the cell cycle. However, we did not find studies of pitaya extract effects on tumoral breast cells in the literature.

Other components have already been well characterized in pitaya and, along with anthocyanins, have been described with substances potentially beneficial to human health. Esquivel et al. [29] found out that betalains containing both phenolic and nonphenolic structures were responsible for the major antioxidant capacity of purple Hylocereus juices evaluated, while nonbetalainic phenolic compounds contributed only to a minor extent. It was 


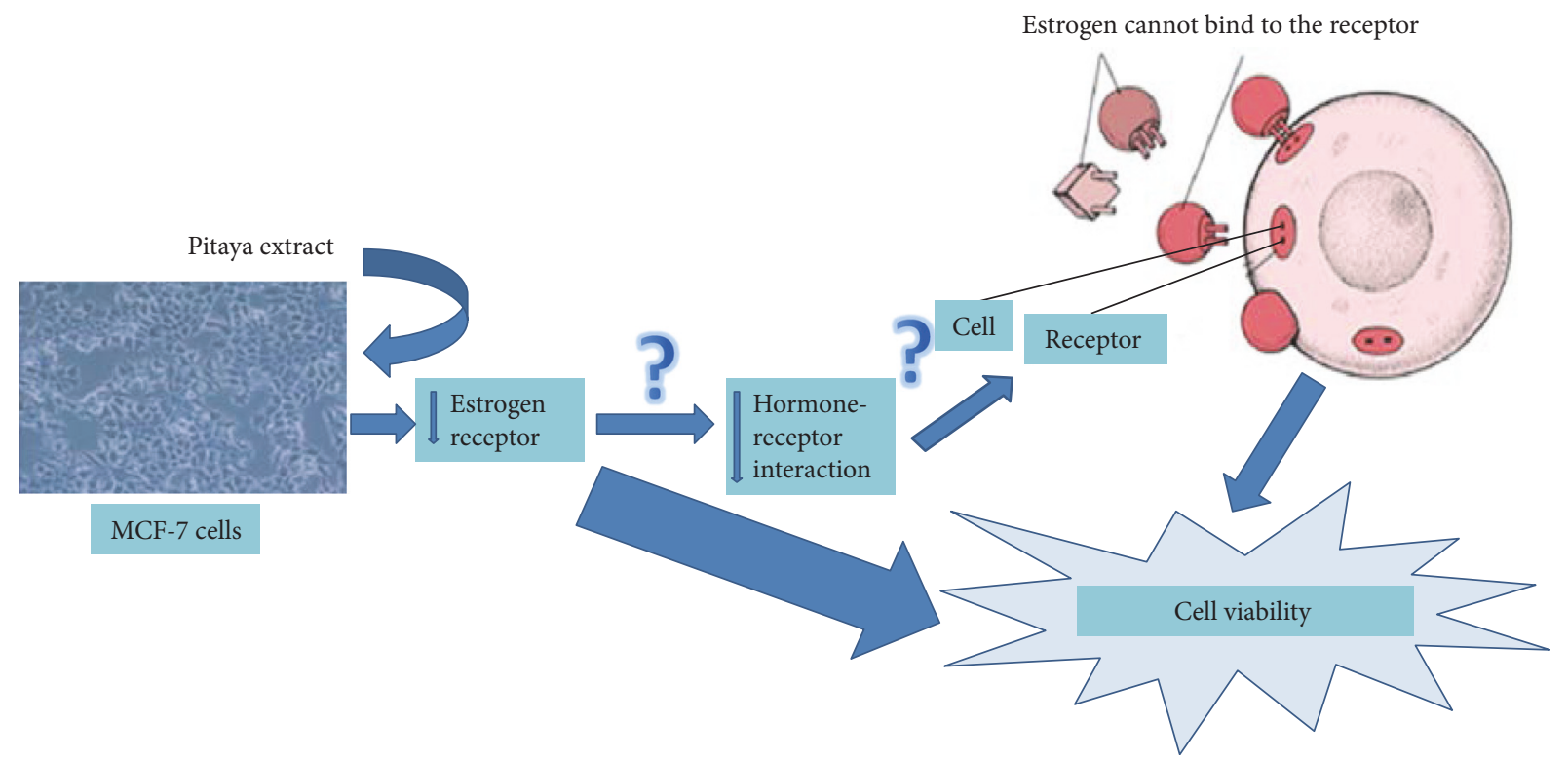

FIGURE 7: The proposed mechanism of action of PE in MCF-7 cells associated with decreased estrogen receptor expression.

once thought that betalains were related to anthocyanins (i.e., a flavonoid derivative), the reddish pigments found in most plants [50].

Estrogen stimulates proliferation of various breast cancer cells via estrogen receptors (ER). Studies show that different compounds present in food matrix could bind to estrogen receptors and mediate estrogen responses [51, 52]. The majority of authors show that there is a positive association between the presence of hormone receptors and a more favorable prognosis. The presence of hormone receptors indicates a functional state closest of normal breast cell. In other words, these tumors are similar in morphology to the cells of origin and thus are less aggressive to the body. The estrogen receptor expression by tumor cells suggests that at least part of cell proliferation depends on stimulation by estrogen. Therefore, it is possible to stop cell growth by blocking hormone [53]. The activity of PE was evaluated in this study to identify potential signaling pathways by realtime PCR analysis; the observations indicate that the PE showed antitumor activity in MCF-7 cell line by probably suppressing $\operatorname{ER} \alpha$.

$\mathrm{BRCA}_{1}$ and $\mathrm{BRCA}_{2}$ are human genes that produce tumor suppressor proteins. These proteins help repair damaged DNA and, therefore, play a role in ensuring the stability of the cell's genetic material. Genetic susceptibility to breast cancer comprises inherited mutations of the $\mathrm{BRCA}_{1}$ and $\mathrm{BRCA}_{2}$ genes related to hereditary breast cancers. In addition, some studies reported that vegetable and fruit intakes were modifiers in developing breast cancer in BRCA mutation carriers [54].

It is known that BRCA-related tumorigenesis is mainly caused by increased genome instability and DNA damage, but it is unclear why patients who have a mutation in $\mathrm{BRCA}_{1}$ $\mathrm{BRCA}_{2}$ are at higher risk of developing estrogen-responsive cancer. Literature suggests that $\mathrm{BRCA}_{1}$ and estrogen and estrogen receptor signaling regulate cell proliferation and differentiation of breast cells, synergistically [55].
$\mathrm{BRCA}_{1}$ and $\mathrm{BRCA}_{2}$ were downregulated upon pitaya treatment, indicating that DNA damage and repair pathways were affected. Proteins (PRAB, $\mathrm{BRCA}_{1}$, and $\mathrm{BRCA}_{2}$ ) playing role in DNA damage response pathway were deregulated upon pitaya treatment [56]. Downregulation of PRAB, $\mathrm{BRCA}_{1}$, and $\mathrm{BRCA}_{2}$ imply that uncontrolled proliferation was to some extent normalized and DNA damage was accumulated leading to apoptosis. Our results on pitaya extract can be reconciled with more general findings in cancer biology that tumors activate DNA damage response pathways such as $\mathrm{BRCA}_{1 / 2}$ upon exposure to DNA-damaging agents [57]. It is worth speculating that pitaya may be even more cytotoxic, if combined with other DNA-damaging drugs such as doxorubicin and cisplatin.

Thomson and Thompson [58] support the emphasis of public messages for greater vegetable and selective fruit intake by extending a potential benefit for ER-negative breast cancer. On the other hand, tumors with positive hormone receptors have a more favorable prognosis and respond better to hormonal therapy. This is because the strategies of treating a malignant tumor sensitive to hormones involve, on the one hand, the reduction of estrogen produced normally by the body and, on the other, the inhibition of the links between receptors and hormones. The first group has use drugs which inhibit the synthesis of the hormone, such as those that reduce the activity of the aromatase enzyme responsible for the synthesis of estrogens in various tissues, such as adipose tissue. Another option, more drastic and in selected cases, would be the surgical removal of the ovaries, which produce estrogens in premenopausal women. In the second group are drugs that aim to disrupt and/or compete with estrogens in its binding to the receptor.

Studies have shown that polymorphisms in the ER $\alpha$ gene (ER-alpha) are associated with diseases such as breast and prostate cancer, osteoporosis, Alzheimer's disease, and cardiovascular diseases [59]. The probable mechanisms of pitaya's proliferative action appear to be dependent on 
decreased $\mathrm{ER} \alpha$ expression that can directly trigger mechanisms of inhibition of cell viability or perhaps decreasing hormone binding to the receptor and thereby inhibiting cell growth (Figure 7). More studies are needed to conclude that the effects of pitaya extract are truly ER-dependent.

\section{Conclusion}

We conclude that pitaya may act on selective ER-responsive breast cancer cells by targeting multiple tumorigenic pathways leading to cell cycle arrest and apoptosis and probably suppress the expression of estrogen and progesterone receptors. Our data indicate that pitaya possesses therapeutic potential against breast cancer. Further preclinical and clinical studies are warranted to clarify the therapeutic potential of pitaya in the prevention and adjuvant treatment of breast cancer.

\section{Conflicts of Interest}

The authors declare that they have no competing interests.

\section{Acknowledgments}

This work was supported by Fundação Carlos Chagas Filho de Amparo à Pesquisa do Estado do Rio de Janeiro (FAPERJ). The funders had no role in the study design, data collection and analysis, decision to publish, or preparation of the manuscript.

\section{References}

[1] R. L. Siegel, K. D. Miller, and A. Jemal, "Cancer statistics, 2016," CA: A Cancer Journal for Clinicians, vol. 66, no. 1, pp. 7-30, 2016.

[2] N. F. Gloria, N. Soares, C. Brand, F. L. Oliveira, R. Borojevic, and A. J. Teodoro, "Lycopene and beta-carotene induce cellcycle arrest and apoptosis in human breast cancer cell lines," Anticancer Research, vol. 34, no. 3, pp. 1377-1386, 2014.

[3] Y. L. Hsu, P. L. Kuo, L. T. Lin, and C. C. Lin, "Asiatic acid, a triterpene, induces apoptosis and cell cycle arrest through activation of extracellular signal-regulated kinase and p38 mitogen-activated protein kinase pathways in human breast cancer cells," The Journal of Pharmacology and Experimental Therapeutics, vol. 313, no. 1, 2005.

[4] G. N. Farhat, S. R. Cummings, R. T. Chlebowski et al., "Sex hormone levels and risks of estrogen receptor-negative and estrogen receptor-positive breast cancers," Journal of the National Cancer Institute, vol. 103, no. 7, pp. 562-570, 2011.

[5] L. G. de Almeida Chuffa, L. A. Lupi-Júnior, A. B. Costa, J. P. de Arruda Amorim, and F. R. Seiva, "The role of sex hormones and steroid receptors on female reproductive cancers," Steroids, vol. 118, pp. 93-108, 2017.

[6] F. M. Blows, K. E. Driver, M. K. Schmidt et al., "Subtyping of breast cancer by immunohistochemistry to investigate a relationship between subtype and short and long term survival: a collaborative analysis of data for 10,159 cases from 12 studies," PLoS Medicine, vol. 7, no. 5, article e1000279, 2010.

[7] X. R. Yang, J. Chang-Claude, E. L. Goode et al., “Associations of breast cancer risk factors with tumor subtypes: a pooled analysis from the breast cancer association consortium studies," Journal of the National Cancer Institute, vol. 103, no. 3, pp. 250-263, 2011.

[8] N. Mavaddat, A. C. Antoniou, D. F. Easton, and M. GarciaClosas, "Genetic susceptibility to breast cancer," Molecular Oncology, vol. 4, no. 3, pp. 174-191, 2010.

[9] D. Hanahan and R. A. Weinberg, "Hallmarks of cancer: the next generation," Cell, vol. 144, no. 5, pp. 646-674, 2011.

[10] F. Turati, M. Rossi, C. Pelucchi, F. Levi, and C. La Vecchia, "Fruit and vegetables and cancer risk: a review of southern European studies," The British Journal of Nutrition, vol. 113, Supplement 2, pp. S102-S110, 2015.

[11] D. Bauer, J. P. de Abreu, H. S. S. Oliveira, A. Goes-Neto, M. G. B. Koblitz, and A. J. Teodoro, "Antioxidant activity and cytotoxicity effect of cocoa beans subjected to different processing conditions in human lung carcinoma cells," Oxidative Medicine and Cellular Longevity, vol. 2016, Article ID 7428515, 11 pages, 2016.

[12] A. M. Bode and Z. Dong, "Cancer prevention research - then and now," Nature Reviews. Cancer, vol. 9, no. 7, pp. 508-516, 2009.

[13] S. A. Ross, "Evidence for the relationship between diet and cancer," Experimental Oncology, vol. 32, no. 3, pp. 137-142, 2010.

[14] K. A. Hirko, W. C. Willett, S. E. Hankinson et al., "Healthy dietary patterns and risk of breast cancer by molecular subtype," Breast Cancer Research and Treatment, vol. 155, no. 3, pp. 579-588, 2016.

[15] C. K. B. Ferrari, "Functional foods and physical activities in health promotion of aging people," Maturitas, vol. 58, no. 4, pp. 327-339, 2007.

[16] R. A. Jaafar, A. R. Ahmad Ridhwan, N. Zaini, and R. Vasudevan, "Proximate analysis of dragon fruit (Hylecereus polyhizus)," American Journal of Applied Sciences, vol. 6, no. 7, pp. 13411346, 2009.

[17] W. Sim Choo and W. Khing Yong, "Antioxidant properties of two species of Hylocereus fruits," Advances in Applied Science Research, vol. 2, no. 3, pp. 418-425, 2011.

[18] S. A. Ross and C. D. Davis, "MicroRNA, nutrition, and cancer prevention," Advances in Nutrition: An International Review Journal, vol. 2, no. 6, pp. 472-485, 2011.

[19] W. Brand-Williams, M. E. Cuvelier, and C. Berset, "Use of a free radical method to evaluate antioxidant activity," $L W T$ Food Science and Technology, vol. 28, no. 1, pp. 25-30, 1995.

[20] L. L. Vindelov, "Flow microfluorometric analysis of nuclear DNA in cells from solid tumors and cell suspensions. A new method for rapid isolation and straining of nuclei," Virchows Archiv. B: Cell Pathology, vol. 24, no. 3, pp. 227-242, 1977.

[21] H. Kim, H. K. Choi, J. Y. Moon, Y. S. Kim, A. Mosaddik, and S. K. Cho, "Comparative antioxidant and antiproliferative activities of red and white pitayas and their correlation with flavonoid and polyphenol content," Journal of Food Science, vol. 76, no. 1, pp. C38-C45, 2011.

[22] E. S. M. Abdel-Aal, J. C. Young, and I. Rabalski, “Anthocyanin composition in black, blue, pink, purple, and red cereal grains," Journal of Agricultural and Food Chemistry, vol. 54, no. 13, pp. 4696-4704, 2006.

[23] B. Ou, M. Hampsch-Woodill, and R. L. Prior, "Development and validation of an improved oxygen radical absorbance capacity assay using fluorescein as the fluorescent probe," Journal of Agricultural and Food Chemistry, vol. 49, no. 10, pp. 4619-4626, 2001. 
[24] R. L. Prior, H. Hoang, L. Gu et al., “Assays for hydrophilic and lipophilic antioxidant capacity (oxygen radical absorbance capacity $\left(\right.$ ORAC $\left._{\mathrm{FL}}\right)$ ) of plasma and other biological and food samples," Journal of Agricultural and Food Chemistry, vol. 51, no. 11, pp. 3273-3279, 2003.

[25] M. D. S. M. Rufino, R. E. Alves, E. S. De Brito, S. M. De Morais, C. D. G. Sampaio, and F. D. Saura-calixto, "Metodologia científica: determinação da atividade antioxidante total em frutas pelo méotodo de reduçao do ferro (FRAP)," Comunicado Técnico Line, vol. 1, pp. 3-6, 2006.

[26] E. A. Shalaby, S. M. M. Shanab, and African Journal of Pharmacy and Pharmacology, "Antioxidant compounds, assays of determination and mode of action," vol. 7, no. 10, pp. 528539, 2013.

[27] S. B. Klein, G. J. Fisher, T. C. Jensen, J. Mendelsohn, J. J. Voorhees, and J. T. Elder, "Regulation of TGF- $\alpha$ Expression in human keratinocytes: PKC-dependent and -independent pathways," Journal of Cellular Physiology, vol. 151, no. 2, pp. 326-336, 1992.

[28] D. Aune, D. S. M. Chan, A. R. Vieira et al., "Fruits, vegetables and breast cancer risk : a systematic review and meta-analysis of prospective studies," Breast Cancer Research and Treatment, vol. 134, no. 2, pp. 479-493, 2012.

[29] P. Esquivel, F. C. Stintzing, and R. Carle, "Phenolic compound profiles and their corresponding antioxidant capacity of purple pitaya (Hylocereus sp.) genotypes," Zeitschrift für Naturforschung. Section C, vol. 62, no. 9-10, pp. 636-644, 2007.

[30] R. Nurliyana, I. Syed Zahir, K. Mustapha Suleiman, and K. Kamarul Rahim, "Antioxidant study of pulps and peels of dragon fruits: a comparative study," International Food Research Journal, vol. 17, pp. 367-375, 2010.

[31] I. Ky and P. L. Teissedre, "Characterisation of Mediterranean grape pomace seed and skin extracts: polyphenolic content and antioxidant activity," Molecules, vol. 20, no. 2, pp. 21902207, 2015.

[32] D. B. Haytowitz and S. Bhagwat, USDA Database for the Oxygen Radical Absorbance Capacity (ORAC) of Selected Foods, Release 2, 2010.

[33] M. R. Maria do Socorro, R. E. Alves, E. S. de Brito, J. PérezJiménez, F. Saura-Calixto, and J. Mancini-Filho, "Bioactive compounds and antioxidant capacities of 18 non-traditional tropical fruits from Brazil," Food Chemistry, vol. 121, no. 4, pp. 996-1002, 2010.

[34] D. L. Holliday and V. Speirs, "Choosing the right cell line for breast cancer research," Breast Cancer Research, vol. 13, no. 4, p. 215, 2011.

[35] C. H. Wang, X. J. Gao, S. Y. Liao, J. X. Feng, B. Luo, and L. X. Liu, "Transcriptome analysis of human breast cancer cell lines MCF 7 and MDA MB 435 by RNA Seq 1," Molecular Biology, vol. 49, no. 2, pp. 244-252, 2015.

[36] Q. Zhang, H. Fan, J. Shen, R. M. Hoffman, and H. R. Xing, "Human breast cancer cell lines co-express neuronal, epithelial, and melanocytic differentiation markers in vitro and in vivo," PLoS One, vol. 5, no. 3, pp. 1-6, 2010.

[37] M. Lacroix and G. Leclercq, "Relevance of breast cancer cell lines as models for breast tumours: an update," Breast Cancer Research and Treatment, vol. 83, no. 3, pp. 249-289, 2004.

[38] J. Ge, A. X. Tian, Q. S. Wang et al., "The GSTP1 105Val allele increases breast cancer risk and aggressiveness but enhances response to cyclophosphamide chemotherapy in North China," PLoS One, vol. 8, no. 6, article e67589, 2013.
[39] X. Chen and B. He, "Oxygen free radical scavenging activity and anti-lipid peroxidation of tea polyphenol," Zhong Yao Cai, vol. 21, no. 3, pp. 141-144, 1998.

[40] P. Cos, T. Bruyne, N. Hermans, S. Apers, D. Berghe, and A. Vlietinck, "Proanthocyanidins in health care: current and new trends," Current Medicinal Chemistry, vol. 11, no. 10, pp. 1345-1359, 2004.

[41] S. Wybraniec and Y. Mizrahi, "Fruit flesh betacyanin pigments in Hylocereus cacti," Journal of Agricultural and Food Chemistry, vol. 50, no. 21, pp. 6086-6089, 2002.

[42] R. Asmah, M. Nor Laili, and A. Mohd Fadzelly, "Free radical scavenging activity of two Hylocereus species (Cactaceae) and their effect on the proliferation of HeLa and MDA-MB231 cancer cell lines," Planta Medica, vol. 74, no. 9, p. PA5, 2008.

[43] G. I. Evan and K. H. Vousden, "Proliferation, cell cycle and apoptosis in cancer," Nature, vol. 411, no. 6835, pp. 342-348, 2001.

[44] C. Y. Looi, A. Arya, F. K. Cheah et al., "Induction of apoptosis in human breast cancer cells via caspase pathway by vernodalin isolated from Centratherum anthelminticum (L.) seeds," PLoS One, vol. 8, no. 2, article e56643, 2013.

[45] J. J. Tyson, W. T. Baumann, C. Chen et al., "Dynamic modelling of oestrogen signalling and cell fate in breast cancer cells," Nature Reviews. Cancer, vol. 11, no. 7, pp. 523-532, 2011.

[46] H. Yao, S. Li, J. Hu et al., "Chromatographic fingerprint and quantitative analysis of seven bioactive compounds of Scutellaria barbata," Planta Medica, vol. 77, no. 4, pp. 388 393, 2011.

[47] L. D. Murad, N. D. Soares, C. Brand, M. C. Monteiro, and A. J. Teodoro, "Effects of caffeic and 5-caffeoylquinic acids on cell viability and cellular uptake in human colon adenocarcinoma cells," Nutrition and Cancer, vol. 67, no. 3, pp. 532-542, 2015.

[48] S. H. Mahassni and R. M. Al-Reemi, "Apoptosis and necrosis of human breast cancer cells by an aqueous extract of garden cress (Lepidium sativum) seeds," Saudi Journal of Biological Sciences, vol. 20, no. 2, pp. 131-139, 2013.

[49] D. Sreekanth, M. K. Arunasree, K. R. Roy, T. Chandramohan Reddy, G. V. Reddy, and P. Reddanna, "Betanin a betacyanin pigment purified from fruits of Opuntia ficus-indica induces apoptosis in human chronic myeloid leukemia cell lineK562,” Phytomedicine, vol. 14, no. 11, pp. 739-746, 2007.

[50] H. Luo, Y. Cai, Z. Peng, T. Liu, and S. Yang, "Chemical composition and in vitro evaluation of the cytotoxic and antioxidant activities of supercritical carbon dioxide extracts of pitaya (dragon fruit) peel," Chemistry Central Journal, vol. 8, no. 1, p. 1, 2014.

[51] G. G. Kuiper, J. G. Lemmen, B. Carlsson et al., "Interaction of estrogenic chemicals and phytoestrogens with estrogen receptor beta," Endocrinology, vol. 139, no. 10, pp. 4252-4263, 1998.

[52] F. Paris, P. Balaguer, B. Térouanne et al., "Phenylphenols, biphenols, bisphenol-A and 4-tert-octylphenol exhibit alpha and beta estrogen activities and antiandrogen activity in reporter cell lines," Molecular and Cellular Endocrinology, vol. 193, no. 1-2, pp. 43-49, 2002.

[53] Early Breast Cancer Trialists' Collaborative Group (EBCTCG), C. Davies, J. Godwin et al., "Relevance of breast cancer hormone receptors and other factors to the efficacy of adjuvant tamoxifen: patient-level meta-analysis of randomised trials," Lancet (London, England), vol. 378, no. 9793, pp. 771$784,2011$. 
[54] K. P. Ko, S. W. Kim, S. H. Ma et al., "Dietary intake and breast cancer among carriers and noncarriers of BRCA mutations in the Korean hereditary breast cancer study," The American Journal of Clinical Nutrition, vol. 98, no. 6, pp. 1493-1501, 2013.

[55] L. Wang and L. J. Di, "BRCA1 and estrogen/estrogen receptor in breast cancer: where they interact?" International Journal of Biological Sciences, vol. 10, no. 5, pp. 566-575, 2014.

[56] T. M. Pawlik and K. Keyomarsi, "Role of cell cycle in mediating sensitivity to radiotherapy," International Journal of Radiation Oncology, vol. 59, no. 4, pp. 928-942, 2004.

[57] K. Cheung-Ong, G. Giaever, and C. Nislow, "DNA-damaging agents in cancer chemotherapy: serendipity and chemical biology," Chemistry \& Biology, vol. 20, no. 5, pp. 648-659, 2013.

[58] C. A. Thomson and P. A. Thompson, "Fruit and vegetable intake and breast cancer risk: a case for subtype-specific risk?" Journal of the National Cancer Institute, vol. 105, no. 3, 2013.

[59] A. Jakimiuk, M. Nowicka, M. Bogusiewicz et al., "Prevalence of estrogen receptor alpha PvuII and XbaI polymorphism in population of Polish postmenopausal women," Folia Histochemica et Cytobiologica, vol. 45, no. 4, pp. 331-338, 2007. 


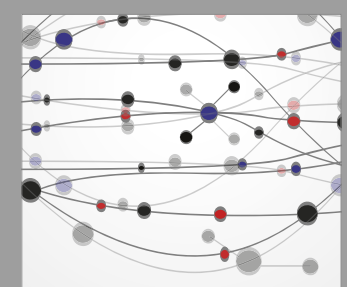

The Scientific World Journal
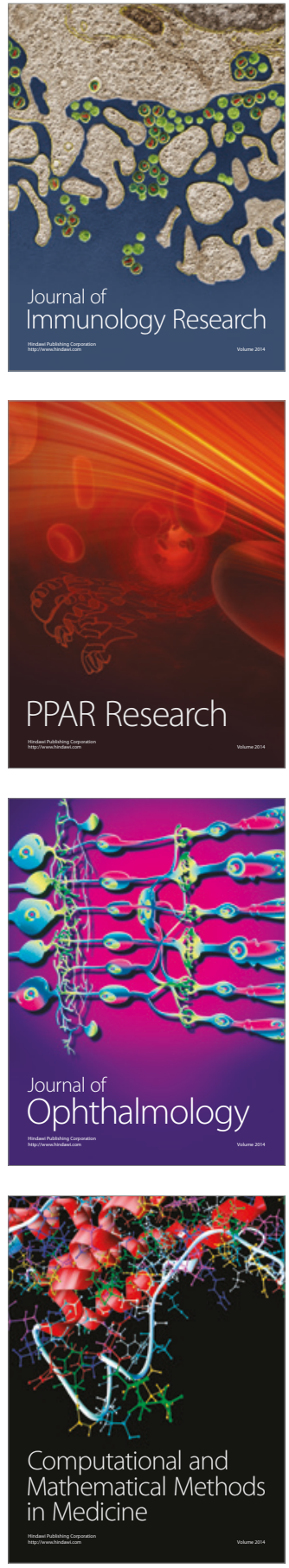

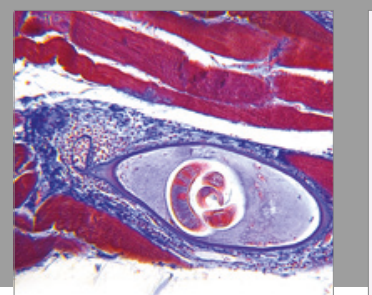

Gastroenterology Research and Practice
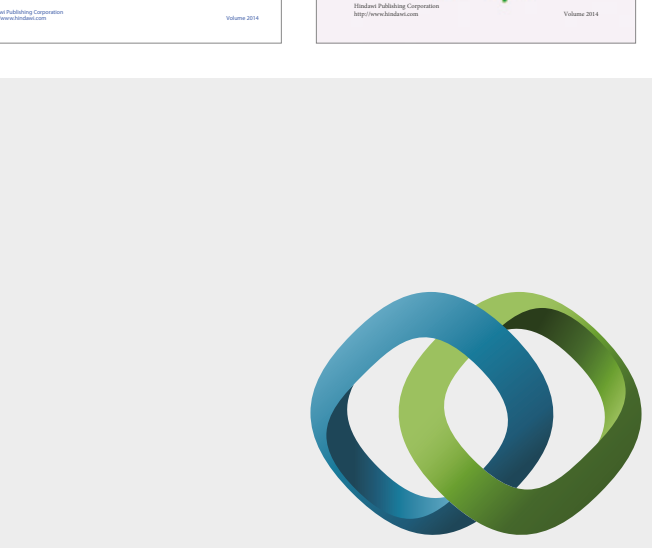

\section{Hindawi}

Submit your manuscripts at

https://www.hindawi.com
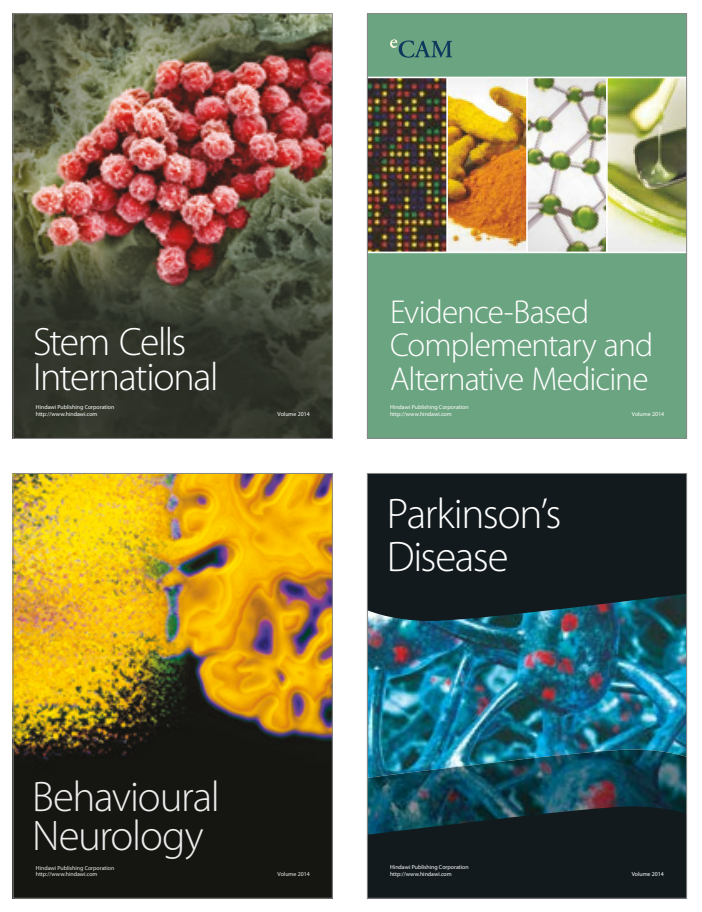
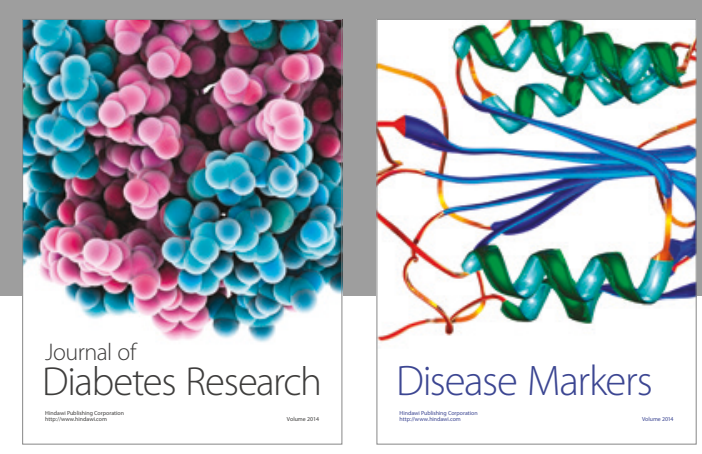

Disease Markers
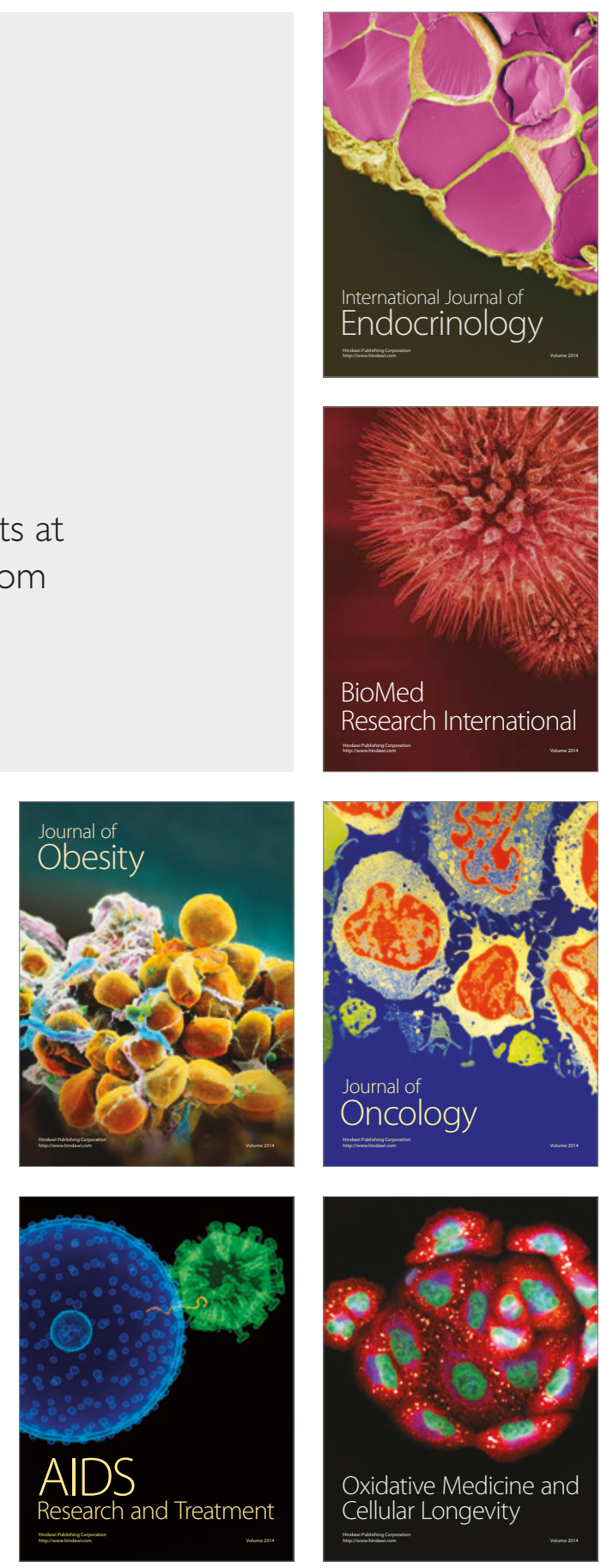